\title{
Differences in Mathematical Problem-Solving Skills Between Students Who Learn By Applying Problem- Based Learning and Project-Based Learning Assisted by Edmodo
}

\author{
Darma Dani Harahap ${ }^{1}$, Budi Halomoan Siregar ${ }^{2}$, Aminah Kaloko ${ }^{3}$, Apriani K. Siagian ${ }^{4}$ \\ \{budihalomoan@unimed.ac.id\} \\ Department of Mathematics Education, Faculty of Mathematics and Natural Science,State University \\ of Medan ${ }^{1,2,3,4}$
}

\begin{abstract}
The purpose of this study was to determine whether there were differences in mathematical problem solving skills between students who learned by applying the problem based learning and project based learning models assisted by edmodo. This type of research is quasi experiment. Furthermore, the sample in this study were students who came from 2 classes consisting of 66 people. Data obtained through observations and tests. Furthermore, to test the hypothesis, inferential statistical analysis method is used. The results of this study show that there are differences in students' mathematical problem solving abilities in the two experimental classes. Where, the problem solving ability of students in the problem based learning class is higher than in the project based learning class
\end{abstract}

Keywords: Problem Solving, Problem Based Learning, Project Based Learning.

\section{Introduction}

Mathematics is a universal science that underlies the development of modern technology and has an important role in solving problems, both theoretically and practically. The importance of developing problem solving abilities has been realized as one of the goals of mathematics education. In order to achieve this goal, it is necessary to apply a learning model that can construct students' knowledge in solving mathematical problems. However, in reality researchers found several problems obtained from observation, interviews, and tests that were given.

The first problem is the students' ability in solving the problem is still low. It can be seen from the four indicators of problem solving ability, namely understanding the problem, a plan division, carrying out the plan, looking back. Based on the results of observations by giving diagnostic tests to 33 students, it is obtained that 3 students empty the answer sheet, 4 students have a low criteria of problem-solving skills that is $55 \%-64 \%$ meanwhile the other 26 students is categorized as having very low problem solving abilities between $0 \%$ - has a very low problem-solving ability that is between $0 \%-54 \%$.

The next problem is the learning-method used is still direct learning with the question and answer method. In addition, teachers also often use low-order thinking skills. So that an alternative and appropriate action is needed to solve the problem. 
Lencher defines mathematical problem solving as "the process of applying mathematical knowledge that has been obtained previously into new, unknown situations". As an implication, problem solving activities can support the development of other mathematical abilities such as communication and mathematical reasoning (Yusuf Hartono, 2013).

To improve students' thinking skills, one of the main programs related to thinking skills is to teach a number of problem solving skills to students. This approach is called the heuristic approach. In the heuristic approach, the aim is to teach certain problem-solving skills which students can use when they have to overcome certain problems. To be able to do it more easily, the problem solving process needs to be deconstructed into composite parts. The

following is the sequence that must be done in problem solving, namely understanding the problem, making a problem solving plan (a plan division), implementing the plan (carrying out the plan), checking back (looking back). (Daniel and David, 2008).

Duck (1994) explain that PBL is an instructional method that challenges students to "learn to learn", work together in groups to find solutions for the real problems. This problem is used to link curiosity and the ability of students to analyze and initiative on learning material. PBL prepares students to think critically and analytically, and to search for and use appropriate learning resources.

Project Based Learning $(\mathrm{PjBL})$ is a model that regulates learning through certain projects. The focus of learning lies in the core concepts and principles of a study discipline, involving students in problem-solving investigations and other meaningful task activities, giving students the opportunity to work autonomously constructing their own knowledge, and culminating in producing real outcomes. (Rais, 2010).

Edmodo is a safe online learning environment and is free from advertisements, games and other distractions that can be used to communicate between educators with students both for lessons and homework, and to collaborate with classmates (Anton, 2017). Edmodo can be used as a learning communication platform to support student learning at the individual, group and whole class levels, both inside and outside the classroom. It also can be used throughout formal and informal situation. The learning settings allow students to collaborate, communicate, submit assignments, upload and download files, and educators to share lesson notes with students, connect to websites, upload and download references for students, making online quizzes, news notifications and event agendas (Kong \& Song, 2014)..

\section{Research methods}

This study used quasi-experimental method. This research was carried out at Telkom Sandhy Putra Medan Vocational School located at Letjend Djamin Ginting No. 9C, Medan Tuntungan. The population was taken from all students of eleventh grade of Telkom Vocational School Sandhy Putra Medan Academic Year 2018-2019. For the sample of the research, one class was used as experimental class 1, namely the class that used Problem Based Learning (PBL) learning models and one class was used as experimental class 2, namely the class that used Project Based Learning (PjBL) learning models and the two classes were assisted by virtual Edmodo.

The variables in this study are independent variables, dependent variables, and control variables. The independent variable in this study is the Problem Based Learning (PBL) learning model and the Project Based Learning ( $\mathrm{PjBL}$ ) learning model and both classes are 
assisted with virtual Edmodo. The dependent variable in this study is the students' ability to solve mathematical problems.

Table 1. Research Design

\begin{tabular}{llll}
\hline Post-test & Treatment & Pre-test & Class \\
$\mathrm{T}_{2(1)}$ & $\mathrm{X}_{1}$ & $\mathrm{~T}_{1(1)}$ & Eksperiment A \\
$\mathrm{T}_{2(2)}$ & $\mathrm{X}_{2}$ & $\mathrm{~T}_{1(2)}$ & Eksperiment B \\
\hline
\end{tabular}

\section{Research finding and discussion}

\subsection{Research finding}

Before given a different treatment, the two experimental classes were first given a pretest. And after being treated with two learning models, post-test was given. The question used a description form, consisted of 3 questions. In summary, the results of the pre-test and posttest of the two experimental classes are presented in the following table.

Table 2. Pre-Test and Post-test Data

\begin{tabular}{lcccl}
\hline Post-test & & Pre-test & & \\
Eksp. & Eksp.1 & Eksp.2 & Eksp.1 & Statistic \\
2 & & & & \\
2336.7 & 2480 & 1610 & 1656.7 & Score \\
70.80 & 75.15 & 48.78 & 50.20 & Mean \\
\hline
\end{tabular}

Based on Table 2 above, it was found that the total and the mean score of pretest and posttest of mathematical problem solving abilities in the experimental class 1 were different from the experimental class 2. Besides being stated differently, the students' score in experimental class 1 was higher than experimental class 2.

In addition, the difference between pre-test and post-test scores is also necessary to discover whether there was an improvement before and after between pre-test and post-test in the two experimental classes is shown in the following diagram. 


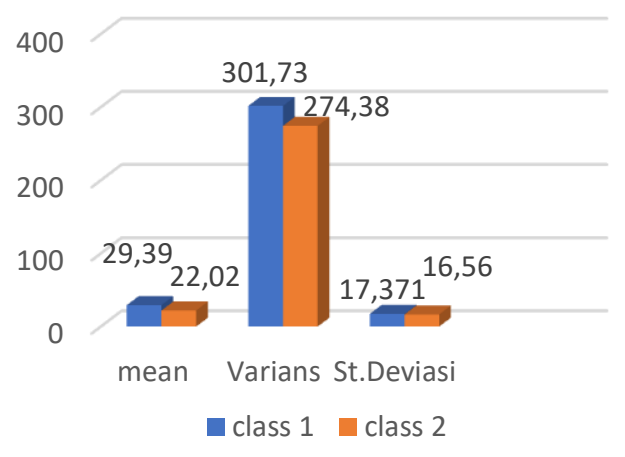

Fig. 1. Difference of pre-test dan post-test

Based on Figure 1, it was found that the average

deviation of pretest-posttest in experimental class 1 was 29.39, while the deviation of pretest-posttest experimental class 2 was 22.02. The data show that the influence of the learning model in experimental class 1 is higher than the experimental class 2 . This is also indicated by the increase of each indicator in both classes as in the following diagram.

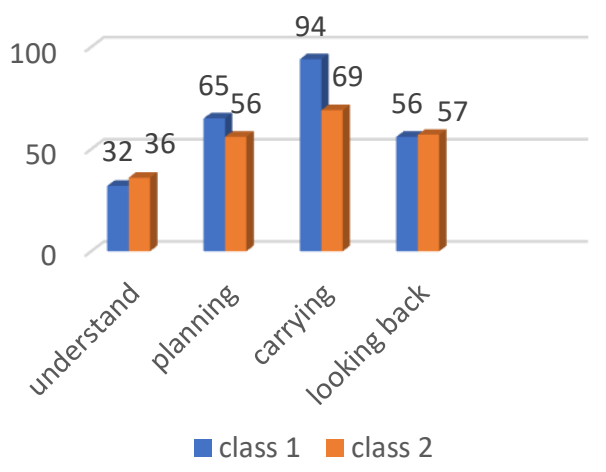

Fig. 2. Difference per indicator of both classes

Based on the score criteria of problem solving ability, and following data will show the number of students based on the criteria of students' mathematical problem solving ability before and after given a mathematical problem solving ability test.

Table 3.Total of based on score criteria of mathematical problem solving ability.

\begin{tabular}{lclllll}
\hline Group. & \multicolumn{2}{c}{ Group. } & Descrp & \\
Eksp 2 & \multicolumn{2}{c}{ Eksp 1 } & & PPS \\
& & & & & Level \\
Post & pret & post & pret & & & \\
est & est & est & est & & & \\
3 & 0 & 6 & 0 & V.High & 90 & - \\
6 & 2 & 9 & 2 & High & 100 \\
\hline
\end{tabular}




\begin{tabular}{llllll}
11 & 3 & 8 & 4 & Avrge & $80-89$ \\
6 & 7 & 5 & 4 & Low & $70-79$ \\
7 & 21 & 5 & 23 & V.Low & $60-69$ \\
& & & & & $\leq 59$ \\
\hline
\end{tabular}

From Table 3 above, it can be seen that the students in the "Very Low" assessment category in both classes experienced a dramatic decrease in the number of students. Whereas for the "Very High" category in both classes at pretest was 0, in the posttest of the experimental class 1 was 6 students and the experimental class 2 was 3 students. Likewise in other categories which show an increase in students' mathematical problem solving abilities before and after treatment.

One of the analytical requirements that must be met in order to use the t-test parametric statistics is the distribution of data must be normally distributed. To test the normality of the data is done by using the Lilliefors test, with normal conditions if Lcount $<$ Ltable at the level of $\alpha=0.05$. The results obtained show that experimental data at the experimental class 1 and 2 are from populations that are normally distributed.

The next is a normal homogeneity test for data. Data homogeneity testing is done by using the F test. Fcount < Ftable means that the population has the same or no different variance.

The data that derived from normal and homogeneous populations, the two-party t-test is used to test the hypothesis. The hypothesis tested is:

Where

$$
\begin{aligned}
& \mu 1=\mu 2 \\
& \mu 1 \neq \mu 2
\end{aligned}
$$

$\mu 1$ : Average difference in posttest-pretest population of Experimental class A

$\mu 2$ : Average difference in posttest-pretest population of Experimental class B

Testing this hypothesis, with rejected criteria $\mathrm{HO}$ if tcount $>$ ttable and accepted if Ho, if $\mathrm{H} 0$ tcount $>$ ttable, which is obtained from the list of $\mathrm{t}$ distributions with $\mathrm{dk}=64$ at the significant level $\alpha=0.05$, for the other $\mathrm{t} \mathrm{H0}$ is rejected. The average difference between posttest pretest in experimental class 1 was 29.39 and the average posttest-pretest difference in experimental class 2 was 22.02. From the posttest data above obtained t_count $=1,7727$ and $\mathrm{t}$ table $=1,6694$ with $\alpha=0,05$ and $\mathrm{dk}=64$, from testing the hypothesis obtained t_count>t_table that is $1,7727>1,6694$ so that $\mathrm{H} 0$ is rejected and $\mathrm{Ha}$ is accepted. So it can be concluded that there are differences in mathematical problem solving abilities of students who were taught using the Problem Based Learning (PBL) model and the Project Based Learning model with Edmodo's help.

\subsection{Discussion}

From the results of the pretest, it was obtained that the average score of students in the experimental class 1 is 50.20 and the experimental class 2 is 48.78 and the initial ability of the two classes is not much different. After knowing the students' initial abilities, different learning is given to the two experimental classes. Experimental class 1 was treated with Edmodo-assisted Problem Based Learning and experimental class 2 was treated with Edmodoassisted Project Based Learning. After the learning process took place for 2 meetings then a post-test was conducted to determine mathematical problem solving abilities in both experimental classes. From the results of the study obtained the average value of the post-test 
experimental class 1 is 75.15 and the average value of the post-test experimental class 2 is 70.80 .

The difference between the problem based learning model and the project based learning model is that in problem based learning the teacher gives problems to students and students learning through the problems given by the teacher. Which is in learning, the teacher involves students to solve a problem through the stages of making hypotheses, designing experiments, conducting investigations, collecting data, interpreting data, making conclusions, discussing and making reports, so that students can learn knowledge related to the problem. Whereas in learning project based learning the teacher does not directly provide problems to students, however, students are given the opportunity to find their own problems by giving project assignments. Projects compiled by groups that have organized membership and division of tasks to produce a project which in this case is a neatly arranged report. This affects the problem solving indicators of each learning model.

From the calculations that have been made, in addition to obtaining the conclusion that there are differences in problem solving abilities of the two classes, we can also see the results of students' scores so that the differences can be compared. After being applied, the two classes get the sum and average results contained in the following diagram

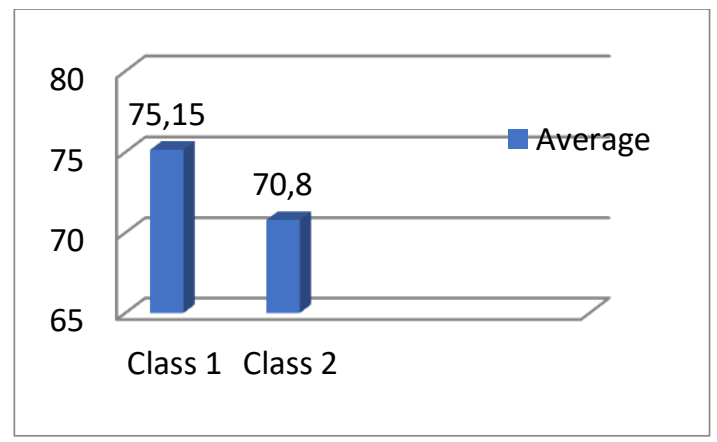

Fig. 3. Posttest Average Score of Two Class

\section{Conclusion}

Based on the results of the study, it can be concluded that there are differences in students' mathematical problem solving abilities taught by Edmodo-assisted Problem Based Learning and Edmodo-assisted Project Based Learning. All indicators of students' mathematical problem solving abilities were improved after the treatments were given in both experimental classes.

\section{References}

[1]Hartono, Yusuf, (2014), Matematika Strategi Pemecahan Masalah, Graha Ilmu. Yogyakarta

[2]Muijs, Daniel dan David, (2008), Effective Teaching, Pustaka Pelajar, Yogyakarta.

[3]Nasrullah, Anton, dkk, (2017), Efektivitas Penggunaan Media Edmodo Pada Pembelajaran Matematika Ekonomi Terhadap Komunikasi Matematis. Pasundan Journal of Research in Mathematics Learning and Education, 1[2]:1 
[4]Rais, Muh, (2010), Project Based Learning: Inovasi Pembelajaran yang berorientasi Soft Skill, UNS. Semarang.

[5]Thomas, J. W. \& Mergendoller, J. R, (2000), Managing project-based learning: Principles from the field. Paper presented at the Annual Meeting of the American Educational Research Association, New Orleans. 